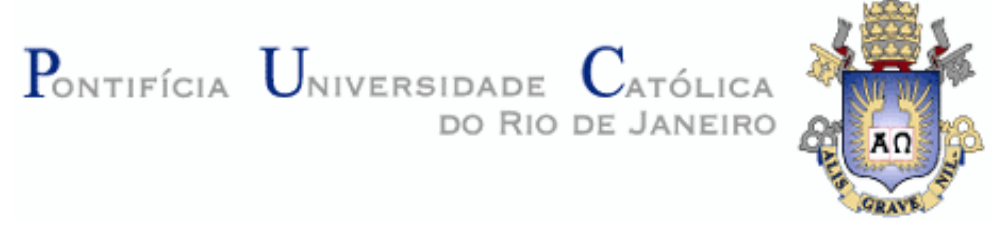

Sonia Telles Ribeiro

\title{
A Verdade Segundo Bresson em Notas sobre o Cinematógrafo
}

Dissertação de Mestrado

Dissertação apresentada como requisito parcial para obtenção do Título de Mestre pelo Programa de PósGraduação em Filosofia do Departamento de Filosofia do Centro de Teologia e Ciências Humanas da PUCRio.

Orientadora: Profa. Kátia Rodrigues Muricy 


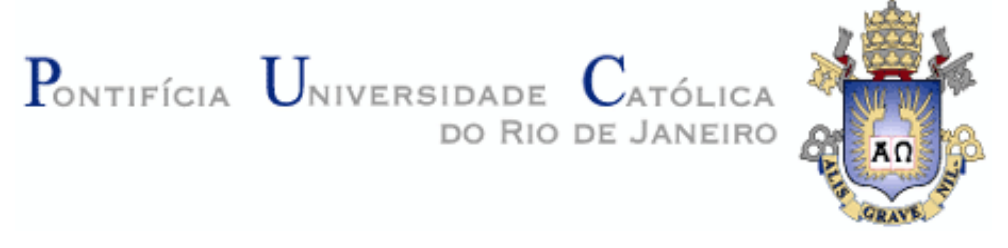

Sonia Telles Ribeiro

\author{
A Verdade Segundo Bresson \\ em Notas sobre o Cinematógrafo
}

Dissertação apresentada como requisito parcial para obtenção do Título de Mestre pelo Programa de PósGraduação em Filosofia do Departamento de Filosofia do Centro de Teologia e Ciências Humanas da PUCRio. Aprovada pela Comissão Examinadora abaixo assinada.

\author{
Profa. Kátia Rodrigues Muricy \\ Orientadora \\ Departamento de Filosofia - PUC-Rio
}

Prof. Pedro Duarte de Andrade

Universidade Federal do Estado do Rio de Janeiro - UNIRIO

Prof. Patrick Estellita Cavalcanti Pessoa

Universidade Federal Fluminense - UFF

Profa. Denise Berruezo Portinari

Coordenadora Setorial do Centro de Teologia e Ciências Humanas - PUC-Rio

Rio de Janeiro, 25 de março de 2013 
Todos os direitos reservados. É proibida a reprodução total ou parcial do trabalho sem autorização da autora, da orientadora e da universidade.

\section{Sonia Telles Ribeiro}

Graduou-se em Ciências Biológicas pela UERJ em 1982. Obteve o grau de Mestre em Zoologia (área de concentração em Ecologia Evolutiva), pela University of Oklahoma, nos EUA, em 1987. Na mesma universidade, fez outra graduação em 1991, em Artes visuais. Em seguida, obteve o grau de Mestre em Artes visuais em 1995, pela Pratt Institute em Nova Iorque. Em 2006, concluiu o curso de Especialização em Arte e Filosofia oferecido pelo CCE/PUC-Rio.

Ficha Catalográfica

Ribeiro, Sonia Telles
A verdade segundo Bresson em notas sobre o
cinematógrafo / Sonia Telles Ribeiro ; orientador:
Kátia Rodrigues Muricy. - 2013.
84 f. ; $30 \mathrm{~cm}$
Dissertação (mestrado)-Pontifícia Universidade
Católica do Rio de Janeiro, Departamento de
Filosofia, 2013.
Inclui bibliografia
1. Filosofia - Teses. 2. Bresson, Robert 3.
Cinema. 4. Verdade. 5. Cinematógrafo. I. Muricy,
Kátia Rodrigues. II. Pontifícia Universidade Católica
do Rio de Janeiro. Departamento de Filosofia. III.
Título.

CDD: 100 
Em memória de minha mãe,

Laura Beatriz. 


\section{Agradecimentos}

À minha orientadora, Professora Kátia Muricy, pela confiança, disponibilidade e orientação ao longo deste trabalho.

Aos professores e colegas do curso pelos ensinamentos compartilhados.

À Edna, Diná, e Leonardo pelo atendimento sempre que precisei.

À CAPES e à PUC-Rio pelos auxílios concedidos.

Ao meu pai e meus irmãos, pela compreensão, apoio e incentivo constantes e fundamentais. 


\section{Resumo}

Ribeiro, Sonia Telles; Muricy, Kátia Rodrigues. A verdade segundo Bresson, em Notas sobre o cinematógrafo. Rio de Janeiro, 2013, 84p. Dissertação de Mestrado - Departamento de Filosofia, Pontifícia Universidade Católica do Rio de Janeiro.

Nesta dissertação, analisamos os aforismos reunidos no livro Notes sur le cinématographe (1975), do diretor Robert Bresson, com o objetivo de delimitar seu conceito de verdade. No livro, Bresson opõe seu ideal do cinema como arte pura, o "cinematógrafo", ao "cinema" contaminado pela estética teatral de representação. $O$ primeiro alcança a expressão verdadeira por ser consistente com sua essência, seguindo os princípios dados nos aforismos. Como estes não são organizados por qualquer tipo de divisão no livro, agrupamo-os em temas e subtemas que discernimos a partir da recorrência de certas palavras. A dissertação concentrou-se nos seguintes temas e sua relação com a verdade: técnicas elípticas contra a representação; realidade e falsidade; a figura do diretor-artista; os "modelos" e o automatismo; composição e montagem. Essa análise reforçou as abordagens que aproximam Bresson das concepções fenomenológicas, pela fundamentação da verdade nas percepções imediatas, pré-reflexivas. Tais sensações devem corresponder à essência do objeto real percebido, e deixam de ser verdadeiras quando a cognição as submete ao sistema linguístico. A verdade não está nas proposições, mas na sensação momentânea da presença do objeto em meio ao "desconhecido" externo e interno ao sujeito. A câmera pode tornar a realidade oculta parcialmente visível, captando os indícios da sua essência. Nos filmes, a composição apresenta essa realidade nas repetidas conjunções entre o desconhecido, em diversas formas de elipses, e a materialidade intensificada das coisas.

\section{Palavras-chave}

Robert Bresson; cinema; verdade; Notas Sobre o Cinematógrafo 


\section{Abstract}

Ribeiro, Sonia Telles; Muricy, Kátia Rodrigues (advisor). The truth according to Bresson, in Notes on cinematography. Rio de Janeiro, 2013, 84p. MSc. Dissertation - Departamento de Filosofia, Pontifícia Universidade Católica do Rio de Janeiro.

In this dissertation, we analyzed the aphorisms collected in the book Notes on cinematography by film director Robert Bresson, to gain a more substantial understanding of his concept of truth. In the book, Bresson opposes his ideal of cinema as a pure art, or "cinematography", to "cinema" contaminated by the representational esthetics of theater. The former attains truthful expression by remaining consistent with its essence, following the principles given in the aphorisms. Since these are not divided into any sections in the book, we grouped them by themes and subthemes discerned mainly through the recurrence of certain words. The dissertation focused on the following themes and their relation to truth: elliptical techniques against representation; reality and falsity; the figure of the director-artist; "models" and automatism; composition and editing. This analysis supported the views that link Bresson to phenomenological conceptions, given his grounding of truth in immediate, pre-reflexive perceptions. Such sensations must correspond to the essence of the perceived real object, and become untrue when cognition submits them to the linguistic system. Truth is not in propositions, but in the fleeting sensation of the perceived object amidst the "unknown", which is both external to and inside the subject. The camera can make the hidden reality partly visible, capturing the glimmer of its essence. In his films, the composition presents this reality in repeated conjunctions between the unknown, in various forms of ellipses, and the intensified materiality of things.

\section{Keywords}

Robert Bresson; cinema; truth; Notes on Cinematography 


\section{Sumário}

1. Introdução

2. Realismo e Verdade 13

2.1. O estilo dos aforismos 13

2.2. Os temas encontrados 15

2.3. Realidade, representação e abstração 17

2.4. O verdadeiro e o falso 28

3. O diretor e os modelos 32

3.1. Aspectos da teoria autoral 32

3.2. O diretor 34

3.3. Os modelos 40

3.4. O modelo e os estilos de atuação 49

4. A composição 51

4.1. A narração paramétrica $\quad 51$

4.2. Ligações, elipses e transformações $\quad 55$

4.3. O Deus oculto 65

5. Conclusão 76

6. Referências bibliográficas $\quad 81$

Anexo - Filmes Citados $\quad 84$ 